DOI 10.38129/Ann.Yur.Ist.2020.4.1.10

УДК 614.23(614.251.2):930.85:17.023.36

\title{
УЯВЛЕННЯ ПРО ТІЛО ТА ЗДОРОВ'Я У ВІДОБРАЖЕННІ СКАНДИНАВСЬКИХ САГ
}

\author{
ВЛАДИСЛАВ КІОРСАК (Львів, Україна)
}

$\mathrm{V}$ «Сазі про Інгі Гарольдссона та його брата» допитливий читач може знайти епізод, у якому змальована жорстока картина замаху на життя благочестивого англійського священника 3 боку синів Гутхрома Сивої Бороди. За словами оповідача, серед чисельних ушкоджень ченець втратив обидва ока. Очні яблука випали після сильного удару, однак ченець зміг знову вставити їх в очні ями, щоправда притримував руками ${ }^{1}$. Такі уявлення середньовічного автора дещо суперечать сучасними знанням про будову людського тіла. Незважаючи на активний розвиток емпіричної медицини у Скандинавії, багато аспектів людського здоров'я, які для сучасних людей здаються очевидними, були неосяжними для тогочасних людей. Сприйняття свого тіла було частиною світогляду людини, оскільки пов'язане частково із релігійними уявленнями та ментальністю, тож Вивчення цъъого сприйняття може прояснити окремі аспекти мислення людей того часу.

Ісландські саги тут хороше джерело - своєрідний зріз епохи, який показує розвиток тогочасних знань зі всіма оманливими уявленнями, міфами та стереотипами, які заповнювали голови людей того часу. Саги часто описують побутові епізоди з життя ісландијі, а ключове для нас повідомлення найчастіше криеться у побіжній інформації, на якій не акцентує сам автор. Для нього, це є чимось само собою зрозумілим ${ }^{2}$. Часто дослідники натрапляють на відверто нелогічні й сумнівні епізоди, згадані у текстах: інколи вони межують із фантастикою, адже описують химерних звірів, чаклунів, згадують про чудеса та розповідають про вигаданих героїв.

${ }^{1}$ Стурлусон С. Круг Земной. - Москва: Наука, 1980. С. 531-532.

2 Більш детально дослідження історизму у сагах див.: Armann J. Nine Saga Studies: The Critical Interpretation of the Icelandic Sagas / Jakobsson Armann. - Reykjavík: University of Iceland press, 2013. - P. 155-171; O`connor R. History or fiction? ThruthClaims and Defensive Narrators in Icelandic Romanse-Sagas / Ralh O`connor. // Maediavel Scandinavia. - 2005. - №15. - P. 101-169. 
На цій підставі окремі вчені відносять дослідження саг в царину вивчення художнъої літератури, пояснюючи це тим, що вони містять мало власне історичної інформації ${ }^{3}$. Однак те, що видається нам фантастичним і не зовсім логічним далеко не завжди було таким для людей Середньовіччя. Працюючи із сагами, ми маємо справу із оповіддю сучасників, а будь-яке їх свідчення буде проходити через призму «історичного» способу мислення. Дракони, ельфи і тролі були частиною цього світогляду, $і$ ще довго та органічно співіснували у свідомості ююдей поряд із пануючою християнською доктриною та, пізніме, науковим розвитком ${ }^{4}$.

У цій статті ми б хотіли розглянути історію медицини середнъовічної Скандинавіі крізь призму анатомічних уявлень тогочасних людей, репрезентованих у ісландських сагах. Це питання, на наше здивування, не викликало широкого зацікавлення у світовій історіографії. Здебільшого проблема медицини в середньовічній Скандинавії ставала предметом коротких розвідок та розділів у науково-популярних книгах, що робить дослідження цього аспекту суспільного життя більш ніж актуальним. Медицина, як окрема наука не виокремилася у вказаному регіоні в період Середньовіччя. Вона не була відмежована від знахарства чи релігійного цілительства, адже випливала із уявлення про природу хвороб, які на думку скандинавів спричинялися ірраціональними чинниками.

Світогляд германських племен був повністю пронизаний фаталізмом. Усе, що відбувалося в житті людини було волею вищих сил. Люди півночі вірили у циклічність життя, яке було наперед визначене богами: вивчаючи середньовічні твори можна помітити, що ці люди надавали великого значення долі. Так, скандинавські воїни вважали, що ключовим фактором будь-якої битви є фортуна, i тому навіть результат бою визначався прихильністю богів. Саме цим були викликані численні ворожіння, про які згадують джерела. Люди прагнули дізнатися чи посміхнеться їм доля, чи ні. Епізод гадання напередодні значної події став класичним для саг. Найбільшим страхом людини було відвернути від себе симпатію богів. Навіть будучи християнами, люди все одно зверталися до провидців. Язичницький спосіб мислення вдало накладався на християнську

${ }^{3}$ Driscoll M. J. What's Truth Got to Do with It? Views on the Historicity of the Sagas / Matthew J. Driscoll. // Самые забавные лживые саги. Сборник статей в честь Г. В. Глазыриной. - 2012. - Р. 15-27.

${ }^{4}$ Jakobsson Á. History of the Trolls? Bárðar saga as an historical narrative / Ármann Jakobsson. // Saga-Book. - 1998. - №25. - P. 53-71. 
концепцію провіденціалізму 5 . Данський автор епохи пізнього Середньовіччя Саксон Граматик пов' язував успіхи та невдачі правителів із прихильністю або гнівом Бога ${ }^{6}$. Цим, на нашу думку, можна пояснити розповсюдженість сюжетів, коли фінал битви вирішувала одна людина. Нерідко це міг бути рядовий воїн, який завдяки своїй природі мав добру долю. Іншим символом є сакральна зброя чи непробивні обладунки, про які часто згадують автори. Усі ці речі були своєрідним амулетом, який гарантував збереження удачі7.

Схожою була ситуація і зі ставленням до недугів.

Добре здоров'я забезпечувалося волею долі й, відповідно, богів. Тому найкрашую профілактикою захворювань було пошанування своїх покровителів, складення жертв, дотримання ритуалів та збереження правильного стану духу. Магія наскрізь пронизували світогляд людей півночі навіть у християнський період. Це добре видно на прикладі тієї ж медицини, яка була частиною релігійного світогляду та випливала із нъого. Розвиток «магічної медицини» Девід Робертсон пов'язує із покровительством Одіна, стародавнього германського бога мудрості ${ }^{8}$. За легендою, він приніс у жертву своє око щоб напитися зі священного джерела Мімір, вода із якого наділяла безмежною мудрістю. Сакральне знання у першу чергу асоціювалося із магією. $У$ «Старшій Еддi» згадуються поради «Високого» (Одіна) про те, як зберегти тілесне та духовне здоров'я, а також як лікувати різні недуги за допомогою рослин та магічних ритуалів ${ }^{9}$. Очевидно Одін був одним із найважливіших покровителів магічної медицини.

5 Turville-Petrs G. Myth and Religion of the North / Gabriel Turville-Petrs. - Westport : Greenwood press publishers, 1975. - P. 253-257; Hultgård A. The religion of the vikings / Anders Hultgård // The Viking world / Anders Hultgård. - London and New York: Roultledge, 2011. - P. 213-215.

${ }^{6}$ Gesta Danorum Liber X [Електронний ресурс] - Режим доступу до ресурсу: http://norse.ulver.com/src/other/saxo/10.html.

${ }^{7}$ MacLeod M. Runic Amulets and Magic Objects / M. MacLeod, B. Mees., 2006. - P. 3-4; Pedersen A. Viking Weaponry / Anne Pedersen // Viking World / Anne Pedersen. London and New York: Roultledge, 2011. - P. 204-211.; Gilchrist R. Magic for the Dead? The Archaeology of Magic in Later Medieval Burials / Roberta Gilchrist. // Medieval Archaeology. - 2008. - №52. - P. 127-128.

8 Robertson D. Magical medicine in Viking Scandinavia / David Robertson. // Medical History. - 1976. - № 20. - C. 318.

9 Беовульф. Старшая Эдда. Песнь о Нибелунгах. - М.: Художественная литература. - 1975. - С. 196-198. 
Ще одним винаходом Одіна було секретне знання рун.

Руни також асоціювалися насамперед із магією. Серед багатьох видів рун, згаданих у «Старшій Едді», згадуються й руни, щзо зиілюють, а також допомагають жінкам при пологах ${ }^{10}$. Сакральний сенс цих знаків повсякчас використовувався під час проведення різних магічних ритуалів. Цікаво, що навіть автори, які жили у часи хрещеної Ісландії, описували магічні ритуали як цілком звичне явище, яке не суперечило християнському світогляду. Так, у «сазі про Егіля» описано історію однієї жінки, яка довгий час не могла вилікуватися від лихоманки. Вона настільки погано себе почувала, що втратила змогу ходити і поступово втрачала розум. Ї̈ батьки звернулися до сина сусідського бонда щоб той вирізав руни для їі зцілення. Однак опісля цієї процедури стан жінки лише погіршився. Тоді батько попросив відомого скальда Егіля Скаллагрімссона допомогти його доньці. Егіль славився не лише даром віршування, а ще й був добрим знавцем рун. На місці, де лежала жінка, він знайшов китовий вус із викарбуваними рунами. Егіль знищив напис і викинув магічний амулет у вогонь. Він сказав, що лише той, хто пізнав мистецтво рун досконало, може ними користуватися, а невмінням може більше нашкодити, аніж принести користі. Тому він наніс нові руни і поклав їх на ліжко жінки. Після цього ритуалу хвора одразу зцілилася, ніби прокинувшись від глибокого сну11.

Вивчаючи північні тексти, Аларік Холл припустив, що скандинави персоніфікували хвороби. Цього висновку він дійшов на основі лінгвістичних порівнянь. Для скандинавів недуг був ритs-ом, тобто монстром, який міг бути як причиною захворювання, так і власне самою хворобою. Така синонімія, на думку автора свідчить про прадавній символізм, який був закладений у світогляді людей того часу. Боротъба iз недугом ототожнювалася із боротъбою проти монстра, а сама хвороба була своєрідною міфологічною сутністю ${ }^{12}$.

Це підтверджують і матеріали ісландських саг. Вони згадують представників скандинавської демонології, як от альвів, гномів та тролей, які мали надприродну силу i таємні знання, могли як шкодити, так i допомагати людям. Злі альви часто насилали хвороби, тому навіть у період

10 Там само. С. 285.

11 Egil Saga. Edited by Bjarni Einarsson - London: Viking Society for Northern Research, 2003. - P. 136-137

12 Hall A. "Pur sarripu pursa trutin": Monster-Fighting and Medicine in Early Medieval Scandinavia / Alaric Hall. / / Revista de Historia de la Medicina y de la Ciencia. - 2009. - P. 195-218. 
християнізації люди часто робили жертвоприношення щоб задобрити цих духів. Пошанування альвів у сагах йменується álfablót ${ }^{13}$. Прихильність цих істот була надзвичайно важливою для тогочасних людей, адже саме вони відповідали за різні хвороби. «Сага про Гьонгу Хрольва» згадує карлика, що жив у землі і міг вилікувати будь-яку хворобу. Завдяки чарівній мазі карлик зміг приростити втрачені кінцівки Хрольва ${ }^{14}$. Однак зробив він це виключно через боязнь бути вбитим розлюченим Хрольвом за усі його попередні огріхи. Адже він ледь не згубив товаришів Хрольва. Про підступність гномів ходили легенди: вони могли зачарувати людей, маніпулювати ї почуттями, закохувати чи псувати стосунки між ними. Інколи демонічні створіння навіть жили поряд із ююдьми, яким завжди доводилося платити високу плату за лікування чи зиілення.

Цікаву інформацію про ельфів подано у «Сазі про Кормака». Один із героїв цього твору, Торвард, отримав поранення під час хольмгангу судового поєдинку, який мав вирішити те, за ким правда у суперечці. Поранення було серйозним і Торвард ніяк не міг одужати. Тоді він звернувся до відьми і та порадила йому принести в жертву бика та окропити його кров'ю пагорб, у якому живуть ельфи. Одразу після ритуалу чоловік почав одужувати ${ }^{15}$.

До відьом та чаклунок часто зверталися у разі хвороби: саме вони виконували роль лікаря у ранньосередньовічному скандинавському суспільстві. До прикладу, у «Сазі про Стюрлауга Працьовитого» згадується стара чаклунка Вефрея, яка могла не лише накладати чари, але також й

13 Sighvats páttr skálds. Pórleifr Jónsson gaf út [Електронний ресурс]. 1904. Режим доступу:http:/ / heimskringla.no/wiki/Fj\%C3\%B6rut\%C3\%ADu_\%C3\%8Dslendinga_ \%C3\%BE\%C3\%A6ttir:_Sighvats_\%C3\%BE\%C3\%A1ttr_sk\%C3\%A1lds.

14 Ця історія викликала сумніви навіть самого переписувача саги. Одразу після опису цього він вставляє ремарку де намагається пояснити те, у чому на його думку може засумніватися читач. «Навіть якщо сьогодні деякі речі можуть видаватися неправдоподібними для окремих людей, кожен повинен відповідати за те, що бачив і чув. Важко заперечити тому, що створили колись мудрі ююди». Цей епізод є гарним зразком втручання редактора у текст саги. Таке втручання $є$ промовистим в контексті співвіднесення різних періодів та світоглядів і суперечності між ними. Цитата за оригінальним виданням Göngu-Hrólfs saga [Електронний ресурс] - Режим доступу до ресурсу: http://norse.ulver.com/src/forn/gonguhrolf/on.html.

${ }^{15}$ Kormáks saga. W. Collinew, trans. In: The Life and Death of Cormac the Skald. AMS Press. 1940. (Reprint) - P. 123. 
лікувати людей. У тому ж творі описуються чаклуни, які мали здатність виліковувати будь-які хвороби ${ }^{16}$.

Однак, куди частіше скандинави вважали чаклунів та відьом причинами різних захворювань. Наприклад, у «Сазі про Інгвара Мандрівника» неодноразово згадуються відьми, які намагалися зачаклувати команду Інгвара17. У «Сазі про людей 3 Піщаного Берега» розповідається про чаклунку Торгунну, яка після смерті повернулася до світу людей i приготувала їжу, й кожен, хто куштував ії починав хворіти та невдовзі гинув. Це продовжувалося доти, доки люди не знищили їі речі, а священник не освятив місце смерті ${ }^{18}$. У «Сазі про Торстейна, сина Вікінга» згадано, що одного разу Вікінг зустрів прекрасну жінку, яка запропонувала йому випити з рогу води. Після того, як він зробив ковток, Вікінг миттєво провалився у сон. Коли він прокинувся, то незнайомки уже не було, однак він відчув слабкість і зрозумів, що серйозно захворів ${ }^{19}$. Цією хворобою була проказа, вона декілька разів згадується у текстах північного походження. Вірогідно інформачію про неї скандинавсъкі автори отримали із християнсъких текстів європейсъкого походження.

Ще одну цікаву історію подає одна із саг про ісландців, «Сага про названих братів». Один із ії героїв, Тормонд, закохався в дівчину, що звалась Торбйорг, й склав на їі честь поему. Однак потім закохався в іншу дівчину і присвятив свій твір вже їй. Торбйорг дізналася про це і вирішила помститися хлопцю. Вона наслала на нього прокляття, через що у нього почалася нестерпна біль в очах. Ця біль пройшла лише тоді, коли Тормонд попросив вибачення і знову присвятив поему Торбйорг ${ }^{20}$.

Взагалі люди того часу надавали великого значення силі слова: вони боялися проклять та за всяку ціну намагалися від них захиститися 21. $У$

16 Глазырина Г. В. Исландские викингские саги о Северной Руси / Галина Васильевна Глазырина. - М.: Научно-издательский центр «Ладомир», 1996. - С. 51.

17 Глазырина Г. В. Сага об Ингваре Путишественнике: Текст. Перевод. Комментарий / Г. Глазырина. - М.: Восточная Литература, 2002. - С. 257-258.

18 The Saga of the Ere-Dwellers translation by William Morris \& Eirikr Magnusson [Електронний ресурс]. - 1892. - Режим доступу до ресурсу: http://sagadb.org/eyrbyggja_saga.en.

19 The Sagas of Fridthjof the Bold translated by Ben Waggoner, The Troth, 2009. - P. 9.

20 Сага о названных братьях. // Исландские саги / - Москва: Языки русской культуры, 2000. - С. 149-151.

${ }^{21}$ Сванидзе А. А. Викинги - люди саги: жизнь и нравы./ Аделаида Анатольевна Сванидзе. - М.: Новое литературное обозрение, 2014. - С. 351-353 
Саксона Грамматика згадано, що король Канут запровадив у своєму війську закони, їх порушників виганяли, а після обряду вигнання їх колишні побратими мали колективно проклинати вигнаниів. Для середньовічного автора таке покарання було чи не найсерйознішим. За словами Саксона солдати настільки боялися провинитися, що жоден не порушив вимог Канута22. Скандинави вірили, що після прокляття людина може позбутися удачі, а це було найгірше для людей, що все своє життя піддавали провіденціалізму.

Отже, медичні уявлення у тогочасному суспільстві були тісно пов'язані із релігійними. Тому професія лікаря ще не встигла виокремитися в суспілствах середньовічної Скандинавіі. У сагах згадуються ююди, які мали дар до лікування, й здебільиого це були жінки високого походження. Наприклад, у «сазі про Стюрлауга Працьовитого» згадано про Інгібйорг, дочку легендарного конунга Pyсі Iнъbapa, що мала невеличку лікарню де надавала допомогу пораненим ${ }^{23}$. « «азі про Олафра Святого» згадується $i$ дружина русъкого князя Ярослава Інгігерд, до якої зверталися ююди у разі серйозних захворюъань 24 . У тому ж творі описано щось схоже на лікарню. Герой цієї саги Тормод був пронизаний стрілою і потрапив у приміщення, де знаходилося багато поранених людей. Місцева лікарка запропонувала надати йому допомогу та перев'язати рани, однак стріла знаходилася занадто глибоко і Тормод попросив вирізати частину плоті, щоб легше було іiі дістати. Коли це було зроблено, Тормод висмикнув стрілу, яка зачепила волокна серця. Від цього чоловік одразу помер 25 .

Проте такі важливі епізоди, де згадуються професійні лікарі, є скоріше виключенням. Зазвичай недужих лікували звичайні люди. У скандинавському війську також не було людей, які б надавали професійну допомогу пораненим: здебільшого це були рядові воїни, які просто вміли правильно перев' язувати рани. Цікаву історію оповідає автор «Саги про Магнуса Доброго». За словами автора, військо норвежців потрапило у халепу під час сутички із племенами вендів. Велика частина воїнів полягла в бою, а ще більше бійців отримало поранення. Лікарів зовсім не вистачало. Король Магнус почав шукати відповідних людей серед війська, він обрав 12 бійців, у яких були найм'якіші руки. Незважаючи на те, що вони не мали

\footnotetext{
22 Gesta Danorum Liber X [Електронний ресурс] - Режим доступу до ресурсу: http://norse.ulver.com/src/other/saxo/10.html.

${ }^{23}$ Глазырина Г. В. Исландские викингские саги. С. 169.

24 Стурлусон С. Круг Земной. - М.: Наука, 1980. С. 341-342.

25 Там само. С. 366-367.
} 
досвіду в лікувальній справі, ці бійці чудово впоралися зі своїм завданням. Як зазначае Снорі Стурлуссон, серед них були також й ісландиі, які після иъого стали відомими медиками. А пізніше від них вели родовід багато лікарів ${ }^{26}$.

Очевидно, що досвід перев'язування ран та надання медичної допомоги мали майже усі скандинави. В умовах частих війн та постійних збройних сутичок поранення були повсякденним явищем. $y$ сагах найчастіше медичним догяядом займалися жінки. Наприклад у «Сазі про Глума Вбивцю» згадано, що дружина Глума покликала жінок, аби вони прийшли на поле бою і надавали допомогу пораненим ${ }^{27}$. Також характерними $є$ епізоди саг, коли воїн зазнавав поранення і його доглядали жінки, або старі люди, які в силу свого похилого віку відзначалися мудрістю та мали хист до цілительства.

Незважаючи на те, що інколи уявлення про тіло та про лікування були фантастичними, скандинави вміли лікувати окремі хвороби.

У сагах часто згадуються люди, що виживали навіть після дуже значних поранень. Те саме засвідчують і матеріали археології. Вчені знаходили скелети людей зі зрощеними після серйозних переломів кістками, що свідчить про те, що ююди жили ще досить довго після поранення ${ }^{28}$. Цікаво також звернути увагу на прізвиська, які мали майже усі люди того часу. Так один із героїв «Саги про людей $з$ Піщаного Берега» отримав прізвисько «Ан Хмиз у шлунку». Таке дивне найменування він отримав завдяки видінню, яке передувало його зціленню. За сюжетом саги, Ан отримав жахливе поранення у битві, його уже вважали мерцем, однак раптово він прокинувся і почав кликати на допомогу. Після того, як його врятували, він розповідав, що до нього приходила жінка, яка витягнула 3 його живота хмиз і вклала туди нутрощі ${ }^{29}$. Саги згадують багатьох людей, які мали прізвиська пов' язані із колишніми ранами. Наприклад «leggr» нога, пов'язують із якимось ушкодженням, або деформацією ноги ${ }^{30}$,

\footnotetext{
26 Там само. С. 393-394.

27 Viga Glum's Saga: The story of Viga-Glum translated by Sir E. Head - London: Williams and Norgate, 1866. - P. 91

${ }^{28}$ A Viking Age cemetery at Cnip, Uig, Isle of Lewis / [A. Dunwell, T. Cowie, M. Bruce та ін.]. // Proceedings of the Society of Antiquaries of Scotland. - 1995. - №125. - C. 739-740.

29 Peterson P. Old Norse Nicknames. A Dissertation Submitted to the Faculty of university of Minnesota by / Paul Peterson., 2015. - P. 121.

30 Ibidem. P. 191.
} 
«hoggvinkinni» - чоловік із порізаною щокою 31 тощо. $\mathrm{Y}$ «Промовах Високого», що є частиною «Старшої Едди», згадано невеликий перелік рослин, які сам бог Одін радить використовувати при різних недугах ${ }^{32}$. Травами лікували багато різних захворювань і часто таке лікування справді мало позитивний ефект.

Велика кількість смертей, пов'язаних із бойовими пораненнями, призвела до розвитку емпіричних знань про будову тіла людини. У сазі «Про названих братів» описано вбивство чоловіка 3 іменем Торгрім Тормондом. У одній із редакцій саги, знайденій в манускрипті, що отримав назву «Flateyjarbók» (Книга з Плоского острова) подано невеличку вставку, де згадано, що в організмі Торгріма було 214 кісток, зубів було 30, а також 415 вен $^{33}$. Окремі із зазначених цифр, як от кількість кісток, та зубів дуже близькі до дійсності. Також у сагах згадується, що скандинави вміли діагностувати окремі хвороби, зокрема і ментальні.

Однак інколи автори саг вдавалися до гіперболізації мужності окремих персонажів. Наприклад у «Сазі про Гіслі» згадується воїн, у якого від сильного удару, який розрізав черево, випали назовні нутрощі. Однак він вклав їх на місце, перев' язав мотузкою живіт та продовжив відчайдушно битися ${ }^{34}$. У «Сазі про людей з Піщаного Берега» згадано, що після битви, коли чоловіки сіли обідати, один із солдатів нічого не їв. Коли його запитали чому він не їсть, виявилося, що у нього в горлі застряг наконечник стріли; коли його витягнули, він почав їсти ${ }^{35}$.

Зрозуміло, що такі інциденти не могли відбуватися насправді. Але для людей того часу вони звучали цілком правдиво. Якщо у випадку історії із карликом, який зумів приростити відрізані ноги воїну, редактор висловлював підозру, то історії із жахливими пораненнями не видавалися фантастичними. Ці тексти належать до циклу «Саг про ісландців», який змальовував повсякденне життя острова. На відміну від інших текстів, які описували історію далеких країн, як ось Норвегія, Данія чи Швеція, саги цього жанру претендували на правдивість, адже тоді жило багато людей,

31 Ibidem. P. 171.

32 Беовульф. Старшая Эдда. Песнь о Нибелунгах. С. 202.

33 Fóstbræðra saga [Електронний ресурс] - Режим доступу до ресурсу: http:/ / norse.ulver.com/src/isl/fostb/is.html.

34 The Story of Gisli the Outlaw. Translated by G. W. Dasent - Edinburg: Edmonston and Douglas, 1866. - P. 110.

35 Сага о Людях с Песчаного Берега. // Исландские саги / - М.: Языки русской культуры, 2004. - С. 97. 
які були сучасниками тих подій, або чули про них від очевидців. Вони б швидко підняли на глум відверту брехню ${ }^{36}$. Саме цей голос автора (у Випадку з карликом) чи мовчання (у випадку із стрілою в горлі) джерелає промовистим для розуміння світогляду середнъовічного скандинавського cycniльсmba. Ці люди жили в межах власних світоглядних рамок і цей ментальний простір допускав існування того, що зараз видається неможливим. Окрім того, ми можемо спостерігати, як змінювався світогляд людей під впливом поширення християнства, наукових знань 3 континенту, а також емпіричних знань 3 анатомії. Цікавим прикладом є також те, як окремі епізоди вступали у конфлікти в свідомості самих переписувачів. Адже часто вони мали справу лише з готовим текстом, який існував в усній формі з прадавніх часів, й інколи автори, яким доводилося працювати із текстами столітньої давності вступали у суперечності із епосом.

Концепиія язичницького детермінізму вдало поєдналася із християнсъкою ідеєю провідениіалізму.

Тільки тепер замість фортуни та прихильності богів у свідомості середньовічного скандинава була Божа Воля. Для людей того часу язичницькі ритуали зберігали своє значення ще довгий час, а спосіб мислення цих людей не зазнав серйозних змін. Наприклад, Саксон Грамматик, оповідаючи про закони короля Канута, згадував, що окрім загального прокляття порушник мав піддатися церковному прокляттю, що остаточно відвернуло би прихильність Бога, а значить - позбавило би доброї долі ${ }^{37}$.

На зміну концепту магічного зиілення, щуо був популярним у язичницький період приходить концепт християнсъкого зиілення вірою. Про такі чудеса досить повно розповів Сноррі Стурлуссон. На початку нашої роботи ми вже згадували благочестивого англійського монаха, який отримав жахливі понівечення та знаходився на межі життя i смерті. Монахові не залишалося більше нічого, окрім як молитися, й завдяки молитві він повністю зцілився. Але тут цікавим є те, кому англійський священник адресував свої молитви. Концепція християнських чудес тісно пов'язана із особою першого святого північного походження - короля Олафа. Саме святому Олафу молився нещасний монах і той з' явився йому у

\footnotetext{
36 Гуревич А. История и сага / Арон Гуревич. - М.: Наука, 1972. - С. 129.

37 Gesta Danorum Liber X [Електронний ресурс] - Режим доступу до ресурсу: http://norse.ulver.com/src/other/saxo/10.html.
} 
видінні, зціливши рани ${ }^{38}$. Його культ настільки сильно укорінився в середньовічній Скандинавії, шо мабуть після Діви Марії та Ісуса він був третім найбільш шанованим i найчастіше згадуваним святим. Пошанування цього святого проявляється у різних місцях Європи та в різні хронологічні періоди. Культ Олафа був поширеним також на Русі та у Візантіі, до прикладу, в Новгороді згадується изерква цзього святого. Незважаючи на те, що офіційна канонізація короля відбулася наприкінці XII ст., його культ почав формуватися практично одразу після смерті. Саме тоді виникають перші твори, що описують чудеса святого Олафа 39.

Ідею «королів-чудотвориів» скандинави скоріш за все запозичили $b$ європейських сусідів, де вона була надзвичайно популярною: у давньоанглійсъких та давньофранцузьких текстах сакралізачія королівськоӥ Влади часто обгрунтовувалася через прояви зиілень та іниих чудес ${ }^{40}$. 3-поміж інших див, які вчинив норвезький король, були і чудеса зцілення людей від різних недугів: лікувальний дар конунга був відомий ще за життя, до нього часто зверталися люди зі своїми проблемами, і нібито він їм допомагав. Наприклад у «Сазі про Олара Святого» згадано, щуо коли король був на Русі, до дружини князя Ярослава Інгігерди прийшла вдова з проханням допомогти вилікувати ї сина, у якого були нариви в горлі. Дружина князя порадила звернутися до Олафа. Олаф освятив хрестом шматок хліба, та дав його з'їсти хлопцю. Після цього йому покращало і згодом від повністю одужав ${ }^{41}$.

У іншому епізоді вказаної саги згадується, що Олаф вилікував свого воїна Егіля, приклавши до хворого місця свою руку42. Коли Торір Собака готував тіло конунга після його смерті, краплина крові Олафа потрапила на рану Торіра, і та одразу зажила. Коли Торір розповів це людям, усі потрактували це як диво ${ }^{43}$. Загалом, цьому святому приписують декілька десятків чудес, серед яких зцілення від німоти, сліпоти, нещасних випадків,

38 Стурлусон С. Круг Земной. - М.: Наука, 1980. С. 532.

${ }_{39}$ Мельникова Е. А. Культ святого Олафа в Новгороде и Константинополе / Елена Александровна Мельникова. // Византийский временник. - 1996. - № 56. - С. 92106.

40 Блок М. Короли-чудотворцы: очерк представлений о сверхъестественном характере королевской власти, распространённых преимущественно во Франции и в Англии / Марк Блок. - Москва: Языки русской культуры, 1998. - С. 85-87.

41 Стурлусон С. Круг Земной. - М.: Наука, 1980. С. 341-342.

42 Там само. С. 316.

43 Там само. С. 364. 
допомога у битвах тощо.

Для ююдей того часу їх тіло було органічною частиною власного мікрокосму, яка піддавалося ірраціональним впливам і розглядалася в системі релігійних вірувань. Незважаючи на розвиток емпіричної медицини, лікарська справа ще довго не відокремлювалася від магії, а ююдський світогляд все ще піддавався містицизму. На зміну язичнииьким жертвоприношенням прийшов християнський обряд, який ще довго зберігав певні риси попередніх культів. Апогеєм цього світогляду у сагах став культ святого Олафа, який одночасно засвідчив міиність позицій місиевого язичництва та значний вплив на скандинавську культуру з боку решти Свропи.

Ісландські саги є важливим джерелом для вивчення цих світоглядних трансформацій, адже у них поєднуються сліди абсолютно різних культур, які інколи суперечать одне одному. Сага є насправді унікальним джерелом, яке межує між історією та літературою. Вона є корисною не мише для вивчення світогляду ююдей із середовища ї̈ творення, але також $і$ для дослідження історії повсякдення Скандинавіі. Особливість саги полягає у тому, щуо ї автори не приділяли великого значення описам побуту, однак, він випливав із тексту сам по собі, як фонова інфрормація, яку не було сенсу умисно фральсифікувати. Часто для реконструкції особливостей життя тогочасних людей доводиться збирати інформацію маленькими уривками $з$ творів, але вона все одно залишається цінною, бо відображає те, як думали люди, як сприитмали себе та навколишніӥ cbim. Вивчення цього аспекту дозволяє певною мірою відтворити у нашій уяві епоху цих людей, а отже, краще їх зрозуміти.

MA in History Vladyslav Kiorsak (Lviv, Ukraine)

Concepts of body and health in the context of Scandinavian sagas

In this article, we would like to examine the history of medicine in medieval Scandinavia through the prism of the anatomical representations of the people of that time set forth in Icelandic sagas. To our surprise, this question never aroused wide interest in world historiography. Basically, the problem of medicine in medieval Scandinavia became the subject of short research and sections in popular science books, which makes the study of this aspect of social life more than relevant. Medicine, as a separate science, did not stand out in this region during the Middle Ages. It was not separated from magic or religious healing, because it stemmed from the idea of the nature of diseases, which, according to the Scandinavians, were caused by a combination of irrational factors.

Key words: History of Medicine, Women in Medicine, Sagas, Herbal Treatment, Wound Treatment. 
магистр Владислав Киорсак (Львов, Украина)

Представления о теле и здоровье в отражении скандинавских саг

В этой статье мы бы хотели рассмотреть историю медицины средневековой Скандинавии через призму анатомических представлений людей той эпохи, изложенных в исландских сагах. Этот вопрос, к нашему удивлению, никогда не вызывал широкого интереса в мировой историографии. В основном проблема медицины в средневековой Скандинавии становилась предметом коротких исследований и разделов в научно-популярных книгах, что делает исследование этого аспекта общественной жизни более чем актуальным. Медицина в качестве отдельной науки не выделилась в указанном регионе в период Средневековья. Она не была отделена от магии или религиозного целительства, ведь вытекала из представления о природе болезней, которые по мнению скандинавов были обусловлены совокупностью иррациональных факторов.

Ключевые слова: история медицины, женщины в медицине, саги, лечение травами, лечение ран.

магістр Владислав Кіорсак (Львів, Україна)

Уявлення про тіло та здоров'я у відображенні скандинавських саг

У цій статті ми б хотіли розглянути історію медицини середньовічної Скандинавії крізь призму анатомічних уявлень тогочасних людей, репрезентованих у ісландських сагах. Це питання, на наше здивування, не викликало широкого зацікавлення у світовій історіографії. Здебільшого проблема медицини в середньовічній Скандинавії ставала предметом коротких розвідок та розділів у науково-популярних книгах, що робить дослідження цього аспекту суспільного життя більш ніж актуальним. Медицина в якості окремої науки не виокремилася у вказаному регіоні в період Середньовіччя. Вона не була відмежована від знахарства чи релігійного цілительства, адже випливала із уявлення про природу хвороб, які на думку скандинавів спричинялися ірраціональними чинниками.

Ключові слова: історія медицини, жінки в медицині, саги, лікування травами, лікування ран.

* Кіорсак Владислав Борисович - магістр історії історичного факультету Львівського національного університету імені Івана Франка, аспірант Інституту українознавства імені Івана Крип'якевича, екс-голова Львівського медієвістичного клубу.

E-mail: vlad.kiorsak@gmail.com. 